\title{
WORKPLACE BULLYING, PSYCHOLOGICAL DISTRESS, AND SATISFACTION WITH LIFE IN MANUFACTURING AND POWER PLANT IN INDONESIA
}

\author{
Arief Hertanto ${ }^{1}$, Dadan Erwandi ${ }^{2}$, Fatma Lestari ${ }^{3}$, Abdul Kadir ${ }^{4}$ \\ Occupational Health and Safety Department, Faculty of Public Health, Universitas Indonesia ${ }^{1,2}$ \\ Disaster Risk Reduction Center, Universitas Indonesia ${ }^{3,4}$ \\ dadan@ui.ac.id ${ }^{1}$
}

\begin{abstract}
Workplace bullying is a long-term continuous act of harassing, offending, or socially isolating someone or negatively affecting one's work. The aim of this study is to compare the incidence of bullying, psychological conditions, and satisfaction with life among workers who work in manufacturing and power plant industries. This was descriptive quantitative using the survey method involving a total of 445 respondents from both types of industry. These respondents participated in this study by answering a questionnaire distributed online. The findings of this study demonstrated that there were no significant mean differences regarding bullying and psychological conditions in the manufacturing and power plant industries. However, it was identified that there were significant differences in terms of accepting negative actions and the level of satisfaction with life among workers, in which some workers experienced bullying and accepted negative actions by their co-workers and direct superiors. The impact of bullying on workers are stress, loss of self-confidence, and difficulties in making decisions which can interfere with their physical and mental health. This will surely affect how workers deal with stressful conditions or get out from stressful conditions caused by bullying. Management should strive to solve the problem of workplace bullying to prevent this problem from becoming a sustainable and continuous problem.
\end{abstract}

Keywords $\quad$ : Bullying, Stress Level, Satisfaction with Life Level.

\begin{abstract}
ABSTRAK
Penindasan (bullying) di tempat kerja adalah tindakan terus menerus dalam jangka panjang yang melecehkan, menyinggung, atau mengucilkan seseorang secara sosial atau memengaruhi pekerjaan seseorang secara negatif. Tujuan dari penelitian ini adalah untuk membandingkan kejadian bullying, kondisi psikologis, dan kepuasan hidup para pekerja yang bekerja di industri manufaktur dan pembangkit listrik. Penelitian ini bersifat deskriptif kuantitatif dengan metode survei dengan melibatkan total 445 responden dari kedua jenis industri tersebut. Responden ini berpartisipasi dalam penelitian ini dengan menjawab kuesioner yang dibagikan secara online. Temuan penelitian ini menunjukkan bahwa tidak ada perbedaan rata-rata yang signifikan mengenai bullying dan kondisi psikologis di industri manufaktur dan pembangkit listrik. Namun, teridentifikasi adanya perbedaan yang signifikan dalam hal menerima tindakan negatif dan tingkat kepuasan hidup di antara pekerja, di mana beberapa pekerja mengalami bullying dan menerima tindakan negatif oleh rekan kerja dan atasan langsungnya. Dampak bullying pada pekerja adalah stres, kehilangan kepercayaan diri, dan kesulitan dalam mengambil keputusan yang dapat mengganggu kesehatan fisik dan mental mereka. Hal ini tentunya akan mempengaruhi bagaimana pekerja menghadapi kondisi stres atau keluar dari kondisi stres akibat bullying. Manajemen harus berusaha untuk memecahkan masalah bullying di tempat kerja untuk mencegah masalah ini menjadi masalah yang berkelanjutan dan berkelanjutan.
\end{abstract}

Kata Kunci $\quad$ : Level Kepuasan Hidup. Level Stres, Penindasan

\section{INTRODUCTION}

Bullying phenomenon has been observed and discussed both internationally and socially during the last decades (Ciby and
Raya, 2015); (Samnani and Singh, 2016); (Samsudin and Isahak, 2020). Several activities are labeled as bullying and these interactions and bullying acts may occur repeatedly and regularly (daily, weekly) 
and in a certain time period (such as around six months). Bullying is a continuous process where the victim of bullying will eventually has a weak position and becomes the target of systematical negative social actions (Salin, 2015);

In several studies on bullying, bullying comes up as a comprehensive concept for demeaning, violent, and intimidating behaviors that are continuously ed at a person for a longer period of time (Bloch, 2012).

Notelars (2010) suggested that bullying may occur in several places and in various forms, including in the workplace, and may link to negative actions, personal harassment, and social isolation (Samsudin and Isahak, 2020). Workplace bullying is not limited to only unjustifiable criticism, sabotage, and/or hiding relevant information. It also includes personal harassment in the form of gossips and rumors, offensive comments, and insulting a person, someone's attitude, or someone's political or religious belief (Salin, 2015).

Workplace bullying is admitted as a phenomenon with global prevalence and an important issue to study in various parts of the world (Einarsen, Hoel, Zapf \& Cooper, 2003; Salin, 2001), (Ciby and Raya, 2015). Hershcovis et al. (2015) stated that workplace bullying is a universal threat in which the global statistics show that this phenomenon spreads rapidly, almost like a global pandemic (Gupta and Bakhshi, 2018). According to a previous study (Salin and Hoel 2011), workplace bullying is a result of a complex and dynamic process with various contributing factors which can be found in various levels of aspect, including job design, work organization, organizational culture, reward system, organizational change, and leadership (Hansen et al., 2015)

Workplace bullying is defined as is an act of harassing, offending, or socially isolating someone or negatively affecting one's work. Person-related bullying is considered to create a form of stress that can lead to negative impacts on workers' health and potentially leads to psychophysical symptoms, mood change, personality change, and mental disorders such as depressive-anxiety disorders, chronic adaptation disorders, and posttrauma stress. Person-related intimidation includes public insults, neglect, shame, rumor spreading, gossips, privacy disruption, screaming, etc. (Beswick, Gore, Palferman, 2006).

Van Heughten (2010) defines workrelated bullying as an act of personal attack, verbal threat, task/job intervention, role intervention, and social isolation that may eventually lead to physical violence. According to (Beswick, Gore, Palferman, 2006), work-related bullying include giving unrealistic tasks, unrealistic deadline, unmanageable work load, unmeaningful tasks, or unclear information and may also create threats to safety (Hsu, Liu and Tsaur, 2019). A study conducted by (Sturmey et al., 2017), (Donnell and Macintosh, 2015) revealed various risk factors for workplace bullying, but individual factors can also play a role in the occurrence of workplace bullying. Some people may be chosen as easy targets due to reasons such as minority group at the workplace (such as women among male-dominated work group or vice versa, physical disabilities, or different ethnicity from the majority).

The emotional impact of bullying is vulnerability and post-trauma stress syndrome. Collins (2001) reported that people who become the target of bullying may experience loss of self-confidence in decision making and capacity to do routine tasks that were previously managed well. These symptoms are consistent with the symptoms reported in several recent studies (Webster, 2016).

Results of several studies have proven that workplace bullying has been identified as the cause of chronical stress in the modern work life (Hurley, et.al,2016) with effects that are devastating, both in the individual level and organizational level (Einarsen \& Nielsen, 2015; Laschinger \& Fida, 2014; Nielsen, Hystad, \& Eid, 2016), 
(Gupta and Bakhshi, 2018). Hauge, Skogstad \& Einarsen (2010) declared that workplace bullying may produce negative consequences. At the level of the worker, it may disturb the worker's physical and psychological health, dignity, satisfaction with work, and commitment. Another study demonstrated that bullying is a severe social stressor despite good and thorough work stressor management which will result in excessive job demand, poor decision making, unclear role, and conflicts among workers (Salin, 2015). The environment of the organization such as the organizational culture and climate; leadership; job and work organization design; organizational and workplace environment change (Salin and Hoel 2011; Samnani and Singh 2012) may become the situational factors that trigger work-lace bullying among individuals (Salin and Hoel 2011), (D’Cruz, 2015).

According to those previous studies, it can be concluded that workplace bullying is very dangerous, both for the workers and for the organization. At the level of the worker, bullying may disrupt mental health, create stress, and disturb performance while at the organizational level, bullying may disturb team balance, system, and work organization that will lead to a huge loss for workers and the company in the future. It is very important for companies to be able to identify the potential workplace bullying issues and their cause so that it will not become an imminent issue that will negatively impact the company's performance.

This study discusses the comparison of workplace bullying in the manufacturing and power plan sectors and its impact on the psychological condition and satisfaction with life among workers in the sectors. The results of this study are expected to be able to provide the overview on the differences and relationship between bullying acts and psychological condition and satisfaction with life among workers in manufacturing and power plant industries.

\section{METHODS}

This study was a quantitative study conducted from the period of September 15 to December 31, 2020 on workers in manufacturing and power plant industries. The population of this study was all permanent, contract, and contractor workers who work in the companies who had been working in the company for at least six months. The primary data were collected using a questionnaire that was distributed online using the "monkey survey' platform. From the total of 544 questionnaire distributed, only $82.8 \%$ or around 445 respondents returned the questionnaire with complete answers.

This study was a cross-sectional study with the type of industry as the independent variable and bullying, psychological condition (distress), and satisfaction with life as the dependent variables. The quantitative data were analyzed using data scanning process and frequency distribution calculation followed by qualitative explanations on the results of the frequency distribution. The quantitative analysis used were univariate and bivariate data analyses.

In this study, the bullying, psychological condition (distress), and satisfaction with life variables were measured using the Negative Acts Questionnaire-Revised (NAQ-R) made and developed by Einarsen, Hoel, and Notelaers (2009) to measure the workplace bullying acts as the item that specifically measure bullying at the workplace based on the factor analysis done in their study. This questionnaire has already been translated to Indonesian and has passed the ethical review from the Ethical Commission for Public Health Research and Community Work of the Faculty of Public Health, Universitas Indonesia (No. 583/UN2/F10/D11/PPM.00.02/2020).

\section{RESULT \\ Respondent Data}

The majority of the respondents $(94.6 \%)$ working in manufacturing and 
power plant industries were male $(n=421)$ with 218 worked in the manufacturing industry and 203 worked in power plant industry. The largest female workforce was seen in the power plant industry $(n=16)$, which was two times higher than the number of women in the Manufacturing industry $(\mathrm{n}=8)$, as seen in Table 1 .

Table 1 Respondent Demographic Data

\begin{tabular}{|c|c|c|c|c|c|c|}
\hline \multirow[t]{2}{*}{ Respondent } & \multicolumn{2}{|c|}{ Manufacture } & \multicolumn{2}{|c|}{ Power Plant } & \multicolumn{2}{|c|}{ Total } \\
\hline & $\mathbf{n}$ & $\%$ & $\mathbf{n}$ & $\%$ & n & $\%$ \\
\hline \multicolumn{7}{|l|}{ Gender } \\
\hline Male & 218 & 96.5 & 203 & 92.7 & 421 & 94.6 \\
\hline Female & 8 & 3.5 & 16 & 7.3 & 24 & .4 \\
\hline \multicolumn{7}{|l|}{$\underline{\text { Age }}$} \\
\hline$\overline{<30}$ & 74 & 32.7 & 101 & 46.1 & 175 & 39.4 \\
\hline $30-40$ & 87 & 38.5 & 77 & 35.1 & 164 & 36.8 \\
\hline$>40$ & 65 & 28.8 & 41 & 18.8 & 106 & 23.8 \\
\hline \multicolumn{7}{|l|}{ Education } \\
\hline$\overline{\text { High School }}$ & 180 & 79.6 & 67 & 30.6 & 247 & 55.5 \\
\hline Diploma 3 - & 43 & 19 & 151 & 68.9 & 194 & 43.6 \\
\hline \multicolumn{7}{|l|}{ Undergraduate } \\
\hline Master-Doctoral & 3 & 1.4 & 1 & 0.5 & 4 & 0.9 \\
\hline \multicolumn{7}{|l|}{ Service } \\
\hline$\overline{<3}$ & 98 & 43.9 & 158 & 72.1 & 256 & 57.9 \\
\hline $4-6$ & 26 & 11.7 & 20 & 9.1 & 46 & 10.4 \\
\hline $7-10$ & 42 & 18.8 & 18 & 8.2 & 60 & 13.6 \\
\hline$>10$ & 57 & 25.6 & 23 & 10.5 & 80 & 18.1 \\
\hline \multicolumn{7}{|l|}{ History of Illness } \\
\hline$\overline{\text { Yes }}$ & 12 & 5.3 & 10 & 4.6 & 22 & 4.9 \\
\hline No & 213 & 94.2 & 192 & 87.7 & 405 & 91 \\
\hline Don't Know & 1 & 0.4 & 17 & 7.8 & 18 & 4.1 \\
\hline
\end{tabular}

According to age, respondents were on average 32 years old $(\mathrm{SD}=1.436)$, with $39.4 \%$ of respondents were under 30 years old $(n=175)$, of which 101 people worked in power plants and 74 people worked in manufactures. Respondents aged 30-40 years old and over 40 years were $36.9 \%$ (164) and 23.8\% (106), respectively. On a closer look, the respondents who work in manufacturing industries who were in the age range of 30-40 years old was 87 , while those who were $>40$ years old was 65 , which was higher than in the power plants.

In terms of education, 247 respondents $(55.5 \%)$ graduated from high school while 194 graduated from Diploma 3 or had undergraduate degree. Only 4 people had a master degree. In Table 1, it is apparent that 151 respondents with D3-undergraduate education worked in power plants, which was higher than those working in the manufacturing industry with the same level of education. Meanwhile, more workers with high school education or equivalent worked in manufacturing industry $(\mathrm{n}=180)$.

In general, according to the length of employment, the average working period of respondents was 1.92 years, with 256 $(57.9 \%)$ had been working for less than 3 years, $46(10.4 \%)$ had worked for 4 to 6 years, $60(13.6 \%)$ had worked for 7 to 10 years, and $80(18.1 \%)$ had worked for over 10 years in their respective company. The majority of workers who had just worked for less than 3 years was seen in the power plants with 158 workers while most respondents with an employment period of above 10 years were seen in the manufacturing industry with 57 people.

In terms of disease history, 405 Respondents $(91.1 \%)$ had no history of illness and only a small percentage (4.9\%) had a history of illness. From the history of illness, there was no significant between respondents working in manufacturing and power plant industries, meaning that the 
respondents knew about the history of their illness. Some of the diseases experienced by respondents were gout (2\%), hypertension (2\%), gastritis (1.8\%), diabetes $(0.9 \%)$, stroke $(0.2 \%)$, and heart disease $(0.2 \%)$.

As seen in Table 2, based on the employment status in both industries, most employees $(n=231,51.9 \%)$ were permanent employees. The remaining employees consisted of contract employees $(n=147$, $33 \%$ ), third party/outsourced employees $(n=63,14.2 \%)$ and four were daily parttime employees (table 2). In terms of position, 180 were operators/admin, with 107 worked in the manufacturing company and the remaining 73 employees worked in the power plants. For the Manager position, there was no significant difference between Manufacturing industry and Power Plants.

In terms of income, $240 \quad(53.9 \%)$ respondents earned above the regional minimum wage, 185 respondents $(41.5 \%)$ had received the same amount as the regional minimum wage, and only a small portion $(4.9 \%)$ received an income below the regional minimum wage. The number of respondents with an income above the regional minimum wage was higher in the power plants $(n=151)$ than in the manufacturing industry. A total of 15 respondents who had an income below the Regional Minimum Wage were identified in the manufacturing industry while only 5 were in the power plants.

Workplace bullying is defined as "repeated behavior that offends, humiliates, sabotages, intimidates, or negatively affects a person's job when there is a power imbalance. This behavior usually recurs over time. The degree of bullying is this study was determined using the negative action questionnaire (Einarsen, Hoel, \& Notelaers, 2009) that consists of 22 types of questions which reflect unpleasant workplace behavior. Respondents were asked to indicate to which extend they experienced negative actions during the last 6 months. The responses to these questions were expressed using a 5-point scale format $(1=$ never; $2=$ sometimes; $3=$ every month; $4=$ every week; $5=$ daily). If the total score was less than <33, the respondent was considered to have never experienced bullying while a score of $33 \leq$ $\mathrm{x} \leq 45$ indicated occasional experience of bullying and a score of $>45$ reflected that the respondent was a victim of bullying.

The respondents' psychological condition (distress) was measured using the Kessler psychological distress scale consisting of 10 questions that reflect a person's experience of anxiety and depression. Respondents gave answers in, a Likert scale $(1=$ good; $2=$ mild mental disorder; $3=$ moderate mental disorder; $4=$ severe mental disorder) (Kessler R, 2011), where a score of $<20$ showed the respondent's mental health was good and the score of 20 $\leq \mathrm{x} \leq 24,25 \leq \mathrm{x} \leq 29$, and $>30$, reflecting mild, moderate, and severe mental disorders, respectively.

Table 2 Employment Status, Position, and Income of Respondents

\begin{tabular}{|c|c|c|c|c|c|c|}
\hline \multirow[t]{2}{*}{ Respondent } & \multicolumn{2}{|c|}{ Manufacture } & \multicolumn{2}{|c|}{ Power Plant } & \multicolumn{2}{|c|}{ Total } \\
\hline & $\mathbf{n}$ & & $\mathbf{n}$ & $\%$ & & $\%$ \\
\hline \multicolumn{7}{|l|}{ Employment Status } \\
\hline$\overline{\text { Permanent Employee }}$ & 93 & 41.2 & 138 & 63 & 231 & 51.9 \\
\hline Contract Employee & 94 & 41.6 & 53 & 24.2 & 147 & 33.1 \\
\hline Third Party & 35 & 15.5 & 28 & 12.8 & 63 & 14.1 \\
\hline Daily/Per Task & 4 & 1.8 & 0 & 0 & 4 & 0.9 \\
\hline \multicolumn{7}{|l|}{ Position } \\
\hline Implementer & 107 & 47.3 & 73 & 33.3 & 180 & 40.5 \\
\hline Staff & 30 & 13.3 & 23 & 10.5 & 53 & 11.9 \\
\hline Supervisor & 27 & 11.9 & 58 & 26.5 & 85 & 19.1 \\
\hline Assistant Manager & 2 & 0.9 & 3 & 1.4 & 5 & 1.1 \\
\hline Manager & 11 & 4.9 & 9 & 4.1 & 20 & 4.5 \\
\hline
\end{tabular}




\begin{tabular}{lcccccc} 
Others & 49 & 21.7 & 53 & 24.2 & 102 & 22.9 \\
\hline $\begin{array}{l}\text { Income } \\
\text { Under Regional }\end{array}$ & 15 & 6.6 & 5 & 2.3 & 20 & 4.6 \\
$\begin{array}{l}\text { Minimum Wage } \\
\text { Same as Regional }\end{array}$ & 122 & 54 & 63 & 28.8 & 185 & 41.5 \\
$\begin{array}{l}\text { Minimum Wage } \\
\text { Above Regional }\end{array}$ & 89 & 39.4 & 151 & 68.9 & 240 & 53.9 \\
Minimum Wage & & & & & & \\
\hline
\end{tabular}

Table 3 Negative action experience

\begin{tabular}{llllllll}
\hline Variable & Indicator & \multicolumn{2}{c}{ Manufacture } & \multicolumn{2}{c}{ Power Plant } & \multicolumn{2}{c}{ Total } \\
\cline { 2 - 8 } & & $\mathbf{n}$ & $\mathbf{\%}$ & $\mathbf{n}$ & $\mathbf{\%}$ & $\mathbf{n}$ & $\mathbf{\%}$ \\
\hline \multirow{2}{*}{$\begin{array}{l}\text { Total Negative } \\
\text { Actions }\end{array}$} & No bullying & 207 & 91.6 & 193 & 88.1 & 400 & 89.9 \\
\cline { 2 - 8 } & $\begin{array}{l}\text { Sometimes } \\
\text { experience bullying }\end{array}$ & 17 & 7.5 & 20 & 9.1 & 37 & 8.3 \\
\cline { 2 - 8 } & Bullying victim & 2 & 0.9 & 6 & 2.1 & 8 & 1.9 \\
\hline Total & & 226 & 100 & 219 & 100 & 445 & 100 \\
\hline
\end{tabular}

The level of satisfaction with life of the respondents was measured by answering 5 questions using a Likert scale consisting of seven options, ranging from "Strongly disagree", to "Disagree", "Somewhat disagree", "Neutral", "Somewhat Agree", "Agree", and "Strongly Agree" (Diener, E., et all, 1985). The scoring for this questionnaire was read as follows: score 31-35: Very satisfied, 26-30: satisfied, 2125: quite satisfied, 20: neutral, 15-19: less satisfied, 10-14: not satisfied, and 5-9: very dissatisfied.
Based on data analysis from the two types of industry shown in Table 3 , it can be seen that on average the respondents had never experienced negative actions at work $(\mathrm{M}=14.53, \mathrm{SD}=5.092)$, with $400(89.9 \%)$ Respondents had never experienced bullying at work, 37 (8.3\%) Respondents sometimes experienced bullying at work, and $8(1.9 \%)$ Respondents became victims of bullying at work ( 2 in the manufacturing industry and 6 in power plants). This indicates that there was bullying in both industries, although the incidence was still small.

Table 4 Experience of being bullied

\begin{tabular}{llllllll}
\hline Variable & \multirow{2}{*}{ Indicator } & \multicolumn{2}{l}{ Manufacture } & Power Plant & \multicolumn{3}{c}{ Total } \\
\cline { 2 - 8 } & & $\mathbf{n}$ & $\mathbf{\%}$ & $\mathbf{n}$ & $\mathbf{\%}$ & $\mathbf{n}$ & $\mathbf{\%}$ \\
\hline \multirow{3}{*}{ Bullying } & Never & 209 & 92.5 & 184 & 84 & 393 & 88.3 \\
\cline { 2 - 8 } & Sometimes & 14 & 6.2 & 25 & 11.4 & 39 & 8.8 \\
\cline { 2 - 8 } & Every month & 2 & 0.9 & 9 & 4.1 & 11 & 2.5 \\
\cline { 2 - 8 } & Every week & 1 & 0.4 & 1 & 0.5 & 2 & 0.4 \\
\cline { 2 - 8 } & Daily & 0 & 0 & 0 & 0 & 0 & 0 \\
\hline Total & & 226 & 100 & 219 & 100 & 445 & 100 \\
\hline
\end{tabular}

Table 5 Distress level

\begin{tabular}{llllllll}
\hline Variable & Indicator & \multicolumn{2}{l}{ Manufacture } & \multicolumn{2}{l}{ Power Plant } & \multicolumn{2}{c}{ Total } \\
\cline { 2 - 8 } & & $\mathbf{n}$ & $\mathbf{\%}$ & $\mathbf{N}$ & $\mathbf{\%}$ & $\mathbf{n}$ & $\mathbf{\%}$ \\
\hline $\begin{array}{l}\text { Distress } \\
\text { Level }\end{array}$ & 195 & 86.3 & 176 & 80.4 & 371 & 83.4 \\
\cline { 2 - 8 } & $\begin{array}{l}\text { Good } \\
\text { Mild Mental } \\
\text { Disorder }\end{array}$ & 21 & 9.3 & 30 & 13.7 & 51 & 11.5 \\
& $\begin{array}{l}\text { Moderate Mental } \\
\text { Disorder }\end{array}$ & 4 & 1.8 & 11 & 5 & 15 & 3.4 \\
& $\begin{array}{l}\text { Severe Mental } \\
\text { Disorder }\end{array}$ & 6 & 2.7 & 2 & 0.9 & 8 & 1.9 \\
\cline { 2 - 8 } Total & & 226 & 100 & 219 & 100 & 445 & 100 \\
\hline
\end{tabular}


To make sure and to confirm that the negative actions indeed happened in both types of industry, researcher asked questions regarding bullying (Table 4). The majority of respondents $(n=393,88.3 \%)$ answered never, $9(8.8 \%)$ answered sometimes, $11(2.5 \%)$ answered every month, and 2 (0.4\%) answered every week. These numbers prove that bullying was indeed occurring in both industries through the link between negative actions and experience of being bullied.

The level of satisfaction with life of the respondents in the two companies is on average very good or, in other words, they were satisfied with working in the company $(\mathrm{M}=23.82, \mathrm{SD}=5,976)$. This is evidenced by the data in Table 6, where $151(34 \%)$ respondents answered "Satisfied", which comprised the majority of the respondents. Other respondents answered "Extremely satisfied" ( $\mathrm{n}=44,9.9 \%)$, "Slightly satisfied" ( $\mathrm{n}=121,27.3 \%)$, "Neutral" $(\mathrm{n}=42,9.5 \%)$, "Slightly dissatisfied" $(\mathrm{n}=58,13.1 \%)$, "Dissatisfied" $\quad(\mathrm{n}=28, \quad 5.6 \%), \quad$ and "Extremely dissatisfied" ( $\mathrm{n}=3,0.7 \%)$. From the average mean in Table 7 , the power plant industry's workers experienced the highest level of satisfaction with life with an average of 23.85 but also had the highest distress level with an average of 15.27, and negative action experience with a mean of 26.67 .

Table 6 Satisfaction with Life Level

\begin{tabular}{llllllll}
\hline Variable & Indicator & \multicolumn{2}{c}{ Manufacture } & \multicolumn{2}{c}{ Power Plant } & \multicolumn{2}{c}{ Total } \\
\cline { 2 - 8 } & & $\mathbf{n}$ & $\mathbf{\%}$ & $\mathbf{n}$ & $\mathbf{\%}$ & $\mathbf{n}$ & \% \\
\hline \multirow{2}{*}{$\begin{array}{l}\text { Satisfaction } \\
\text { with Life Level }\end{array}$} & Extremely Satisfied & 22 & 9.8 & 22 & 10 & 44 & 9.9 \\
\cline { 2 - 8 } & Satisfied & 70 & 31.1 & 81 & 37 & 151 & 34 \\
\cline { 2 - 8 } & Slightly Satisfied & 73 & 32.4 & 48 & 21.9 & 121 & 27.3 \\
\cline { 2 - 8 } & Neutral & 23 & 10.2 & 19 & 8.7 & 42 & 9.5 \\
\cline { 2 - 8 } & Slightly Dissatisfied & 24 & 10.7 & 34 & 15.5 & 58 & 13.1 \\
\cline { 2 - 8 } & Dissatisfied & 10 & 4.4 & 15 & 6.8 & 25 & 5.6 \\
\cline { 2 - 8 } & Extremely Dissatisfied & 3 & 1.3 & 0 & 0 & 3 & 0.7 \\
\hline Total & & 225 & 100 & 219 & 100 & 445 & 100 \\
\hline
\end{tabular}

Table 7 Descriptive Statistical Analysis Results

\begin{tabular}{lllll}
\hline Variable & Type of Industry & n & Mean & SD \\
\hline \multirow{2}{*}{ Total Negative } & Manufacture & 226 & 25.93 & 4.77 \\
Actions & Power Plant & 219 & 26.67 & 6.68 \\
& Total/Mean & 445 & 26.3 & 5.79 \\
\hline \multirow{3}{*}{ Stress Level } & Manufacture & 226 & 14.41 & 5.084 \\
& Power Plant & 219 & 15.27 & 5.074 \\
& Total/Mean & 445 & 14.83 & 5.092 \\
\hline \multirow{3}{*}{ Satisfaction with Life } & Manufacture & 226 & 23.78 & 5.87 \\
& Power Plant & 219 & 23.85 & 6.09 \\
& Total / Mean & 445 & 23.82 & 5.976 \\
\hline
\end{tabular}

To see the whether the data were normally distributed and homogeneous, the Kolmogorov Smirnov test and Levene's test for equality were performed. Data were said to be normally distributed and homogeneous in this study if the p-value> 0.05 . From the results of the Kolmogorov Smirnov test, it was revealed that all p- values were $<0.05$, so the data were not normally distributed. As for the homogeneity test, the levels of distress and satisfaction with life presented a p-value> 0.05 so that the data were deemed homogeneous, while the total negative action data was not homogeneous. 
Table 8 Data Normality and Homogeneity Test

\begin{tabular}{lllll}
\hline Variable & \multicolumn{2}{l}{$\begin{array}{l}\text { Kolmogorov } \\
\text { Smirnov }\end{array}$} & \multicolumn{2}{l}{$\begin{array}{l}\text { Levene's Test for } \\
\text { Equality of Variances }\end{array}$} \\
\cline { 2 - 5 } & Statistics & Sig & F & Sig \\
\hline Total Negative Actions & 0.204 & 0.000 & 6.352 & 0.012 \\
Distress level & 0.498 & 0.000 & 1.707 & 0.192 \\
Satisfaction with Life & 0.095 & 0.000 & 1.738 & 0.188 \\
\hline
\end{tabular}

To identify the difference in the average mean of bullying, distress level, and satisfaction with life in the manufacturing and power plant industries, it was necessary to do an Independent t-test. The hypotheses in this study were:

$\mathrm{H}_{01}$ : There was no difference in the mean of significant negative action experience between the Manufacturing Industry and Power Plant. $\mathrm{H}_{02}$ : There was no difference in the mean of significant bullying experience between the Manufacturing Industry and Power Plant. $\mathrm{H}_{03}$ : There was no difference in the mean of distress level between the Manufacturing Industry and Power Plant. $\mathrm{H}_{04}$ : There was no difference in the mean of satisfaction with life level between the Manufacturing Industry and Power Plant. The t-test used was the Mann Whitney nonparametric test, because the respondent's data were not normally distributed and were not homogeneous.

Table 9 Mann Whitney Test Results

\begin{tabular}{lll}
\hline Variable & $\mathbf{Z}$ & Sig -2 tailed (p-value) \\
\hline Total Negative Actions & 0.381 & 0.703 \\
Bullying & 2.808 & 0.005 \\
Distress level & 2.127 & 0.033 \\
Satisfaction with Life Level & 0.128 & 0.898 \\
\hline
\end{tabular}

Based on the results of the Mann Whitney test (Table 9), it can be concluded that for the negative action variable, the $\mathrm{p}$ value was > 0.05 (0.703); thus, the $\mathrm{H}_{01}$ could not be rejected, meaning that there was no significant difference in the mean for bullying between the Manufacturing and Power Plant industries. The variable of bullying experience received a $\mathrm{p}$-value of $<$ 0.05 (0.005); thus, $\mathrm{H}_{02}$ was rejected, meaning that there was a significant difference in the mean for bullying between the Manufacturing and Power Plant industries.

The distress level variable received a $p$ value $<0.05$ (0.033); thus, $\mathrm{H}_{03}$ was rejected, meaning that there was a significant difference in the mean for distress level between the Manufacturing and Power Plant industries. For the satisfaction with life variable, the p-value was $>0.05$ (0.898); thus, $\mathrm{H}_{03}$ could not be rejected, meaning that there was no significant difference in the mean for satisfaction with life between the Manufacturing and Power Plant industries.

From this study, it can be seen that there were significant mean differences in the bullying ( $\mathrm{p}$-value $=0.005)$ and psychological condition/distress level variables $(p$-value $=0.033)$. However, there was no significant difference in the total negative action variable $(p$-value $=0.703)$ and the satisfaction with life level (p-value $=0.898$ ) in these two types of industry. The difference in cases of bullying in the two industries was identified from the 39 respondents who sometimes experienced bullying (14 in Manufacturing industry and 25 in Power Plants), 11 respondents who experienced bullying every month (2 respondents in Manufacturing industry and 9 respondents in Power Plants) and 2 respondents who experienced bullying every week, 12 respondents (3 in Manufacturing Industry, 9 in Power Plant) 
claimed to have experienced bullying from their direct superiors, 12 respondents ( 2 in Manufacture industry, 10 in Power Plants) admitted to experience bullying from other superiors in the organization, and 34 respondents (7 in Manufacturing industry, 27 in Power Plants) admitted that they experienced bullying from coworkers. Bullying was performed by the respondent's co-workers and direct superiors every week with the majority of the perpetrators are men $(n=36): 13$ in manufacturing industry and 23 in power plants. The number of male perpetrators was 1-2 people was mentioned by 26 respondents and 3-4 male perpetrators were mentioned by 10 respondents.

We also tried to look at the data in more depth from the individual aspects. It was demonstrated that several respondents experienced negative actions in both types of industries. Negative actions received on a daily basis is categorized as bullying. The survey showed that 8 respondents ( 2 in Manufacturing industry and 6 in Power Plants) were victims of bullying because they received negative action intensively. Five $(1.1 \%)$ respondents experienced negative actions such as doing task below competency every day with 4 of the 5 respondents worked in power plants, Three $(0.7 \%)$ respondents experienced negative action in the form of rumors and gossips every day, $2(0.4 \%)$ felt intimidated every month, $2(0.4 \%)$ respondents felt that they became the object of sarcasm every day, 16 (3.6\%) respondents felt that they were constantly reminded of their mistakes every day, $5(1.1 \%)$ respondents felt that they received criticism every day, and 7 (1.6\%) respondents felt that they were always under excessive supervision when working. In addition, $5(1.1 \%)$ respondents felt that their opinions or ideas were ignored and were given the title that they were not proper workers. They also claimed that this experience happened repeatedly, either daily or weekly, lasting more than six months. From this analysis, it can be concluded that bullying occurs more frequently in the power plant industry and that most of the bullies are fellow workers.

Analysis of this study also revealed that there were $4(0.9 \%)$ respondents who sometimes felt restless and anxious, 25 $(5.6 \%)$ felt so anxious so they could not sit quietly (14 in manufacturing industry and 11 in power plants), $2(0.3 \%)$ felt depressed at any time so that no one is able to comfort them, $47(10.6 \%)$ felt that everything they wanted required hard work (26 in Manufacturing and 21 in Power Plant). This psychological condition also affects the productivity of the respondents. which was reflected from the fact that $5(1.1 \%)$ respondents were unable to work or carry out normal activities between 5 - 10 days because they experienced serious mental disorders $(\mathrm{n}=1)$ and mild mental disorder $(\mathrm{n}=4)$. It was also revealed that $5(1.1 \%)$ respondents were only able to do half or less than what they were usually able to do and $12(2.7 \%)$ of the respondents experienced serious mental disorders that required them to consult a doctor (5 in the manufacturing industry and 7 in the Power Plant).

The survey also found that symptoms of distress in these two types of industry include $8(1.8 \%)$ respondents who felt very tired at any time for no good reason, felt nervous/anxious all the time, and felt desperate and hopeless. As a result of the high stress level, there were $15(3.4 \%)$ respondents with mental disorders who were absent from work due to illness and 8 $(1.8 \%)$ respondents with high mental disorders who did not come to work due to illness. Of the 8 respondents with severe mental disorders, they felt that physical health problems were the main cause of being unproductive. One respondent was identified to suffer from chronic gastritis and diabetes mellitus. The relationship between negative actions and level of distress was evidenced by the linear regression test, with the results of a p-value of $0.0005, \mathrm{R}=0.322, \beta=1.713$, constant $=$ 0.499 . 
There is a very significant relationship ( $\mathrm{p}$-value $=0.0005)$ between negative actions and the level of distress (psychological condition) with a strong relationship $(\mathrm{r}=0.568)$ and a positive pattern. In addition, the line equation can explain $32.2 \%$ of the variation in the level of distress, and the addition of negative actions will increase the distress level by 1.7312. Almost all positions have serious mental disorders, consisting of 4 workers, 3 supervisors, and 1 manager. From the perspective of the respondent's education, it turns out that those with D3 education (3 people) and undergraduate education (5 people) have serious mental disorders. This proves that cases of bullying occur evenly across all levels of position and are not related to the level of education.

Theoretically, people who have a higher education should be more capable to deal with stress. Respondents' satisfaction with life in both industries is very good. This in indicated by the data where the average proportion shows that $195(43.8 \%)$ respondents were very satisfied, 121 (27.2\%) respondents were quite satisfied, 42 respondents $(9.4 \%)$ were neutral, 58 respondents (13\%) were slightly dissatisfied, 28 respondents $(6.3 \%)$ felt very dissatisfied, and 3 of them feeling very extreme dissatisfaction. Even though there were $8(1.8 \%)$ respondents who were victims of bullying, only 2 respondents expressed dissatisfaction and 4 respondents felt slightly satisfied while 2 respondents said they were quite satisfied. Although 37 $(8.3 \%)$ respondents stated that they sometimes experienced bullying, only 7 respondents felt slightly dissatisfied and 3 respondents were dissatisfied. To see the relationship between negative actions and the level of satisfaction with life, a line equation was used, and the result showed that there was a very significant relationship ( $\mathrm{p}$-value $=0.0005$ ) between negative actions and the level of satisfaction with life, albeit weak, and the pattern of the relationship was positive Also, the line equation can explain the $4.3 \%$ variation in the level of life satisfaction, and each addition of negative actions will reduce the level of life satisfaction by 0.213 .

\section{DISCUSSION}

This study aimed to determine the differences and overview on the relationship between bullying, psychological condition, and satisfaction with life among workers in the manufacturing and power plant industries. Based on data analysis from the two types of industry, it can be seen that on average the respondents had never experienced negative actions at work $(\mathrm{M}=14.53, \mathrm{SD}=$ 5.092), with 400 (89.9\%) Respondents had never experienced bullying at work, 37 (8.3\%) Respondents sometimes experienced bullying at work, and $8(1.9 \%)$ Respondents became victims of bullying at work ( 2 in the manufacturing industry and 6 in power plants). This indicates that there was bullying in both industries, although the incidence was still small.

From the perspective of negative actions, it was demonstrated that several respondents in both types of industries experienced negative actions. Negative actions received on a daily basis is categorized as bullying, thus 8 respondents ( 2 in Manufacturing industry and 6 in Power Plants) were considered as victims of bullying because they received negative action intensively. The types of negative actions experienced were doing task below competency $(1.1 \%)$, become the object of rumors and gossips $(0.7 \%)$, felt intimidated $(0.4 \%)$, became the object of sarcasm $(0.4 \%)$, constantly reminded of their mistakes $(3.6 \%)$, received criticism $(1.1 \%)$, under excessive supervision when working $(1.6 \%)$, and have opinions or ideas ignored and being labeled as not proper workers $(1.1 \%)$. These negative actions are performed either daily or weekly, lasting more than six months. The analysis in this study also demonstrated that bullying occurs more frequently in the power plant 
industry and that most of the bullies are fellow workers.

This study supports a previous study conducted by Namie (2011) who argued that the form of workplace bullying includes pretending to be kind and sweet in front of people (36\%), providing continuous criticism (29\%), limiting resources and time in work (26\%), as well as scolding, cursing, and giving threats (9\%), (Namie, 2011). According to Einarsen and colleagues (2003), power imbalance plays a central feature in workplace bullying because it can arise between people in different positions such as between individuals, between managers and subordinates, and between groups and individuals. Therefore, this action can be considered different from one-time act of aggression and conflict because the behavior continues over a longer period of time (Galang and Jones, 2015). The results of a previous study conducted by (Staale, Einarsen and Abergen, 2009) showed that workplace bullying is a negative interpersonal behavior committed by coworkers or supervisors towards the respondents and is performed repeatedly and continuously.

According to Pheko (2018), rumors and gossip can be used to widen the power gap between the victim and the perpetrator/s in complex bullying behavior to strengthen the power imbalance, so it is important to understand this phenomenon (Pheko, 2018). Workplace bullying can also take the form of psychological disturbances felt by respondents as a result of shouting orders, constant criticism, and continuous blaming (Arifin, Nirwanto and Manan, 2019). Leadership quality also plays an important role in creating a working condition that leads to workplace bullying (Hansen et al., 2015).

The impact of bullying on workers includes physical fatigue, mental disorders, and decreased performance. Quoting the opinion of a previous study, Miles et.al (2002), (Namie, 2011) suggested that perception of the work environment, such as interpersonal conflicts, triggers negative emotions that are positively correlated with counterproductive behavior. Workplace bullying, such as disparaging comments, constant criticism of work, and withholding resources, can do more harm to respondents. This can affect the individual's ability to work well and will produce a negative impact on the organization (Hsu, Liu and Tsaur, 2019). Hutchinson, Wilkes, Jackson and Vickers (2010) conveyed their view in their study that workplace bullying is a serious and destructive work-related phenomenon so that its effects on individuals can be direct and indirect (Rai and Agarwal, 2017).

Clarke (2005) suggested that the same corporate/organizational psychopaths have been noted to use manipulative skills to dominate the people they work with, exploit them, engage them in sexual relations, spread rumors, and engage in office politics, especially to exaggerate themselves and achieving their goals even engaging in bullying as a tactic to humiliate subordinates. Quoted from Glambek et al. (2014), support from coworkers and increased self-esteem for being part of a group can help reducing some of the perceived symptoms of work-related stress, such as bullying. On the other hand, a decrease in self-identity in work groups and organizations can result in a higher intention to leave the organization (Galang and Jones, 2015).

The psychological condition (level of distress) of workers in both types of industry in this study presents a low risk for mental health disorders or, in other words, the workers in the two industries are in a very good psychological condition. This is evidenced by $370(83.1 \%)$ workers are in good psychological condition, with an almost similar number in both industries. However, of all workers who experience mild mental disorders $(11.7 \%)$, moderate mental disorders (3.4\%), and serious mental disorders $(1.8 \%)$, the majority works in the power plants. Hence, it can be stated that the psychological 
condition/distress level of workers in the power plants is higher than those workers in manufacturing industry. Yet, further analysis shows that among those with very serious mental health, the number of workers who work in the manufacturing industry is higher than those who work in power plants. This supports the findings of Namie (2013) that there are 4 behaviors that are adopted when facing stress: being alone and away from family $(33.4 \%)$, selfdestruction (32.3\%), positive behavior $(24.5 \%)$, and mental disorders $(9.8 \%)$ (Namie, 2013).

Empirical studies on workplace bullying have clearly demonstrated the painful impact in victims of bullying in terms of stress level. Many studies have shown that workplace bullying has adverse health and well-being consequences. Therefore, it appears that victims of workplace bullying feel ashamed and guilty as well as anxious, depressed, and experience sleep disturbances (Vedaa et al., 2016), headaches, cardiovascular and respiratory diseases (Høgh et al., 2012), and even acute pain (Saastamoinen, Laaksonen, Leino-Arjas, \& Lahelma, 2009)). In addition, studies have also found that victims of workplace bullying suffer from post-traumatic stress disorder (PTSD) (Leymann \& Gustafsson, 1996; Matthiesen \& Einarsen, 2007; Mikkelsen \& Einarsen, 2002), (Vukelić, Čizmić and Petrović, 2019). The physical and psychological health consequences associated with stress due to bullying are more extreme than the effects of other types of harassment in the workplace (Namie, 2013). The results of this study also demonstrated that the higher the level of workplace bullying is, the higher the level of stress or psychological disorders.

The status of permanent employee, length of work for more than 3 years, income that is higher than the Regional Minimum Wage, and education above high school produce a tendency for a higher level of satisfaction. Furthermore, the dynamics of work in the manufacturing and power plant industries emphasize teamwork and mutual support between leaders and respondents, so that the level of satisfaction with life tends to be good. Respondents who were reported to be a target of workplace bullying also reported to get a high level of social perceptual support so that they had much greater life satisfaction than their peers who received low social support (Carroll and Lauzier, 2014).

A previous study showed that individuals who experience bullying will show lower job satisfaction compared to individuals who have never experienced bullying at work (Galang and Jones, 2015). Respondents who experience bullying will experience increased level of stress and very extreme dissatisfaction with life. This can have physical consequences, which sometimes lead to the physical manifestation of stress, including headache, sleep disturbance, decreased energy and fatigue, weight change, gastrointestinal problems, heart problems, and chronic illnesses. Another impact is an increase in absenteeism and a decline in performance.

\section{CONCLUSIONS}

The impact of bullying on workers are stress, loss of self-confidence, and difficulties in making decisions which can interfere with their physical and mental health. Bullying is often carried out by one or several people to one or several other people who unwittingly perform bullying in the form of intimidation, sarcasm, gossip and rumors, giving jobs below competency, giving criticism, and constant reminder of past mistakes without realizing that bullying can harm health, cause psychological problems and reduce the performance of workers that is reflected in decreased productivity and decreased selfconfidence. Management should strive to solve the problem of workplace bullying to prevent this problem from becoming a sustainable and continuous problem. Leaders can help respondents who 
experience mental disorders caused by bullying through provision of training and counseling and inviting them to do positive and useful things such as praying, exercising regularly, thinking positively, gathering with family or friends, and doing hobbies or fun things.

\section{ACKNOWLEDEGEMENT}

The authors would like to thank for two companies (Agriculture Manufacturing Industry and Power Plant Industry) that participated in our study, Occupational Health and Safety Department, Faculty of Public Health, Universitas Indonesia (UI) and Disaster Risk Reduction Center UI for the support during completing this study.

\section{REFERENCES}

Arifin, Z., Nirwanto, N. and Manan, A. (2019) 'Reducing the Negative Bullying at Work Impact on Employee Performance through Absorption and Team Work', 64, pp. 885-892. doi: 10.2991/piceeba218.2019.79.

Bloch, C. (2012) 'How do perpetrators experience bullying at the workplace ?', 5(2).

Carroll, T. L. and Lauzier, M. (2014) 'Workplace Bullying and Job Satisfaction: The Buffering Effect of Social Support', Universal Journal of Psychology, 2(2), pp. 81-89. Available at: http://www.hrpub.org.

Ciby, M. and Raya, R. P. (2015) 'Workplace Bullying: A Review of the Defining Features, Measurement Methods and Prevalence across Continents', IIM Kozhikode Society \& Management Review, 4(1), pp. 38-47. doi: $10.1177 / 2277975215587814$.

D'Cruz, P. (2015) Depersonalized Bullying at Work From Evidence to Conceptualization.

Donnell, S. M. O. and Macintosh, J. A. (2015) 'Gender and Workplace Bullying: Men 's Experiences of
Surviving Bullying at Work'. doi: 10.1177/1049732314566321.

Galang, L. . M. and Jones, E. S. (2015) 'Keeping A Distance: Social Identity, Workplace Bullying, and Job Satisfaction', 44(0).

Gupta, R. and Bakhshi, A. (2018) 'Workplace bullying and employee well-being: A moderated mediation model of resilience and perceived victimization', Journal of Workplace Behavioral Health. Informa UK Limited, trading as Taylor \& Francis Group, 33(2), pp. 96-115. doi: 10.1080/15555240.2018.1464929.

Hansen, M. et al. (2015) 'Quality of Leadership and Workplace Bullying: The Mediating Role of Social Community at Work in a Two-Year Follow-Up Study'. doi: 10.1007/s10551-015-2996-3.

Hsu, F.-S., Liu, Y. and Tsaur, S.-H. (2019) 'The impact of workplace bullying on hotel employees' well-being', International Journal of Contemporary Hospitality Management, 31(4), pp. 1702-1719. doi: 10.1108/ijchm-04-2018-0330.

Namie, G. (2011) 'Types of Bullies'.

Namie, G. (2013) 'Offsetting the Pain from Workplace Bullying'.

Pheko, M. M. (2018) 'Rumors and gossip as tools of social undermining and social dominance in workplace bullying and mobbing practices: A closer look at perceived perpetrator motives', Journal of Human Behavior in the Social Environment. Routledge, 28(4), pp. 449-465. doi: 10.1080/10911359.2017.1421111.

Rai, A. and Agarwal, U. A. (2017) 'Linking workplace bullying and work engagement: The mediating role of psychological contract violation', South Asian Journal of Human Resources Management, 4(1), pp. 4271. doi: $10.1177 / 2322093717704732$.

Salin, D. (2015) 'Risk factors of workplace bullying for men and women: The role of the psychosocial and physical 
work environment', Scandinavian Journal of Psychology, 56(1), pp. 6977. doi: 10.1111/sjop.12169.

Samnani, A. K. and Singh, P. (2016) 'Workplace Bullying: Considering the Interaction Between Individual and Work Environment', Journal of Business Ethics. Springer Netherlands, 139(3), pp. 537-549. doi: 10.1007/s10551-015-2653-X.

Samsudin, E. Z. and Isahak, M. (2020) 'Individual antecedents of workplace victimisation: The role of negative affect, personality and self-esteem in junior doctors ' exposure to bullying at work', (October 2019), pp. 1-18. doi: 10.1002/hpm.2985.

Upton, L. (2010) 'THE IMPACT OF WORKPLACE BULLYING ON INDIVIDUAL AND ORGANISATIONAL WELLBEING IN A SOUTH AFRICAN CONTEXT AND THE ROLE OF COPING AS A MODERATOR IN THE BULLYING - WELL-BEING RELATIONSHIP Leanne Upton', (February).

Vukelić, M., Čizmić, S. and Petrović, I. B. (2019) 'Acceptance of Workplace Bullying Behaviors and Job Satisfaction: Moderated Mediation Analysis With Coping Self-Efficacy and Exposure to Bullying', Psychological Reports, 122(5), pp. 1883-1906. doi: 10.1177/0033294118793985.

Webster, M. (2016) 'Challenging workplace bullying: the role of social work leadership integrity', Ethics and Social Welfare, 10(4), pp. 316-332. doi: 10.1080/17496535.2016.1155633 